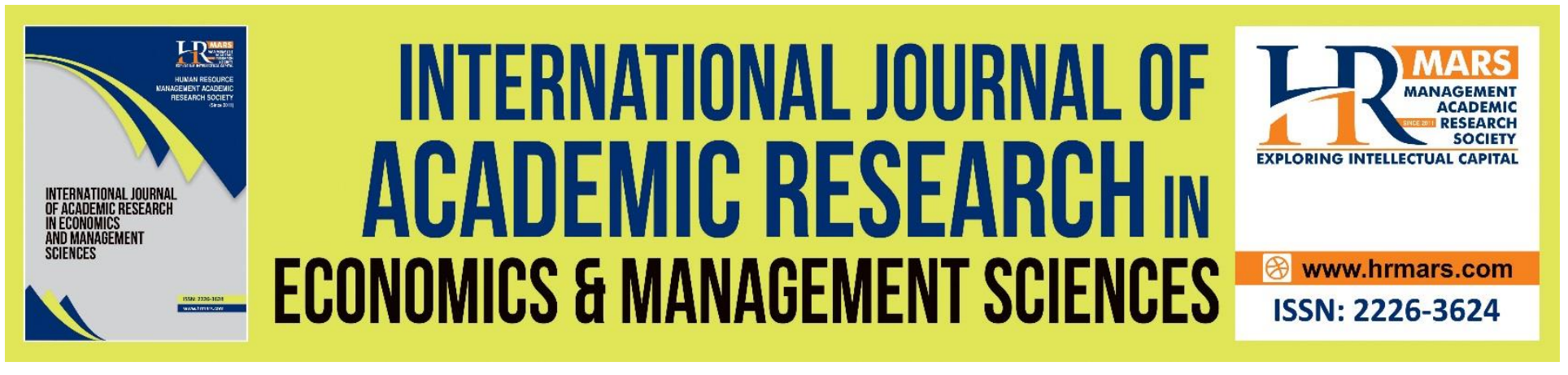

\title{
Preliminary Study on New Border Town in Serudong, Kalabakan: Impacts, Issues and Potentials
}

Rafiq Idris, Kasim Mansur, Diana Nabila Chau Abdullah, Zuraidah Jamrin, Azmi Abdul Majid and Rizal Zamani Idris

To Link this Article: http://dx.doi.org/10.6007/IJAREMS/v10-i4/11996

DOI:10.6007/IJAREMS/v10-i4/11996

Received: 08 October 2021, Revised: 16 November 2021, Accepted: 30 November 2021

Published Online: 19 December 2021

In-Text Citation: (Idris et al., 2021)

To Cite this Article: Idris, R., Mansur, K., Abdullah, D. N. C., Jamrin, Z., Majid, A. A., \& Idris, R. Z. (2021). Preliminary Study on New Border Town in Serudong, Kalabakan: Impacts, Issues and Potentials. International Journal of Academic Research in Economics and Management and Sciences, 10(4), 83-93.

Copyright: (C) 2021 The Author(s)

Published by Human Resource Management Academic Research Society (www.hrmars.com) This article is published under the Creative Commons Attribution (CC BY 4.0) license. Anyone may reproduce, distribute, translate and create derivative works of this article (for both commercial and non-commercial purposes), subject to full attribution to the original publication and authors. The full terms of this license may be seen at: http://creativecommons.org/licences/by/4.0/legalcode

Vol. 10, No. 4, 2021, Pg. 83 - 93

Full Terms \& Conditions of access and use can be found at http://hrmars.com/index.php/pages/detail/publication-ethics 


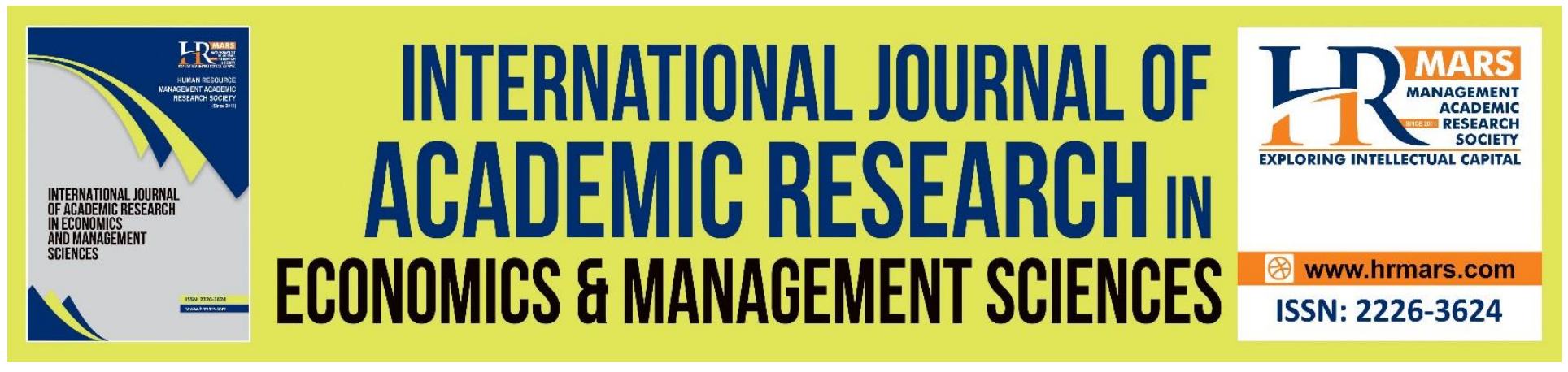

\title{
Preliminary Study on New Border Town in Serudong, Kalabakan: Impacts, Issues and Potentials
}

\author{
Rafiq Idris ${ }^{1}$, Kasim Mansur², Diana Nabila Chau Abdullah ${ }^{3}$, \\ Zuraidah Jamrin ${ }^{3}$, Azmi Abdul Majid ${ }^{3}$ and Rizal Zamani Idris ${ }^{1}$ \\ ${ }^{1}$ Senior Lecturer, Universiti Malaysia Sabah, ${ }^{2}$ Professor, Universiti Malaysia Sabah, \\ ${ }^{3}$ Lecturer, Universiti Malaysia Sabah.
}

\begin{abstract}
In the past few years, Borneo island had witnessed some promising development plans and announcements made by various governments. In Indonesia, the government announced that there will be relocation of Indonesia's capital city from Jakarta to East Kalimantan. In Malaysia, the federal government announced that there will be allocation for road project to connect Sabah with North Kalimantan. In Sabah, the state government did announce that there is plan to have new border town in Serudong. The new border town proposal has invited various positive reaction. At the same time, there were also some concern with regard to the impact and issues associated with the new border town. This preliminary work attempts to study the views of various stakeholders, especially the business community and households in Tawau and Kalabakan, by engaging them via focus group discussion and interview.
\end{abstract}

Keyword: New Border Town, Serudong, Impacts, Issues, Potentials

\section{Introduction}

In 2019, during the 2020 national budget announcement, the federal government announced that RM600 million was approved for the plan to have road link with North Kalimantan, specifically in Serudong-Simanggaris. However, due to CoVID-19, the project was somehow postponed.

When the state government was taken over by a new government, the idea was then pushed again. While pushing for the road construction, there was also thought for having border town in Kalabakan. In April 2020, the state government announced that Sabah shall have a border town in Serudong, Kalabakan when it announces its 5 -year development plan under the Sabah Maju Jaya initiative.

In general, a border town is a town or city situated close to the boundary between two countries, states, or regions. Border towns can have highly populated communities, a feature they share with port cities, as traveling and trading often go through the town or just a small town with some basic infrastructures where people just stop by. From another 
SCIENCES

Vol. 10, No. 4, 2020, E-ISSN: 2226-3624 @ 2020 HRMARS

perspective, a border town can be flashpoints for international conflicts, especially when the two countries have border disputes.

When the idea of constructing road in Serudong to connect with Simanggaris (North Kalimantan) was first coined years back, various ideas have been highlighted by numerous stakeholders. There were discussions on the ideal way of having border town, the location of border town, justification of having border town, the infrastructure needs in border town, the ongoing issues with regard to cross-border activities, size of the new township, the development priorities in border area and the impact of having new border town on economy, security and environment among others. Just like many different border town models around the world, the border town to be developed in Kalabakan if materialized in the next few or some years shall consider various suggestions by numerous stakeholders. This study therefore attempts to identify and highlight some of the key concern and suggestions by undertaking a survey in the district of Tawau and Kalabakan.

\section{Definition \& Perspective of Settlement in Rural Areas, Urban Areas, Towns or Cities}

Definitions of urban, rural, towns or cities are not conclusive for all countries. Many countries use a minimum population size to define an urban area, but that size can be different in different countries. This can be seen obviously when comparing countries with significant population size difference such as Argentina, Denmark, India, China and Japan. Several countries don't use a statistical definition but determine urban areas by administrative decision. In some other countries, the employment sector or provision of infrastructure and services is used to determine whether settlements should be classified as urban or rural.

Towns or cities can be categorized by the importance of their functions. In reality many towns or cities have played many functions. There are many ways settlements or cities /towns being defined or categorized. In the literature there are towns types called as industrial town, holiday town, satellite town, port town and satellite town among others.

In addition, there are four types of settlements. They are compact settlements, semicompact or helmeted cluster, semi-sprinkled or fragmented settlements and sprinkled or dispersed type.

In Malaysia, generally, there are about 3 functions of urban and rural settlements. Firstly, from economic perspective, the urban settlement may play the function as port city, tourism city, industrial city, mining city or IT city. Secondly, for the social function, a city or town may act as a satellite city/town, Royal city/town or education city. Thirdly, a city or township may play the role of providing government services such as military town, border town or administrative town.

Definitions may bring implications such as from financial allocation angle. In normal case, once an area categorized as rural or urban it will remain, hence unchanged. Area in certain country, where getting reclassified as urban may cause places to lose government transfers or allocation. In other instances, where getting classify as urban would trigger additional public investment for higher-level service delivery requirements such as police stations and courthouses. 
SCIENCES

Vol. 10, No. 4, 2020, E-ISSN: 2226-3624 @ 2020 HRMARS

Due to differences in national definitions of urban and rural areas, it is difficult to compare these areas across national borders. In the event that comparison is not possible, that implies that performance of urban or rural areas across national borders not possible also, hence, it is not easy to learn policies used in other countries. That also indicates that meaningful comparison of the United Nations (UN) Sustainable Development Goals' (SDGs) indicators for urban and rural areas across countries not possible.

For that reasons a coalition of six international organizations have developed a new global definition of cities, towns and semi-dense areas, and rural areas to facilitate international comparisons. UN Statistical Commission endorsed the Degree of Urbanization as a recommended method for international comparisons in march 2020.

The Degree of Urbanization have identified three types of settlements. Firstly, the cities, is defined as area which have a population of at least 50,000 inhabitants in contiguous dense grid cells (more than 1,500 inhabitants per $\mathrm{km}^{2}$ ). Secondly, Towns and semi-dense areas, are defined as having a population of at least 5,000 inhabitants in contiguous grid cells with a density of at least 300 inhabitants per $\mathrm{km}^{2}$ and last but least Rural areas, which consist mostly of low-density grid cells.

\section{Malaysia's Bordertown/area: A Snapshot}

In this section, Malaysia's border towns/areas are divided into three parts, which refer to three countries on which Malaysia has border town with. Figure 1 shows the name of border town or areas on which Malaysia is bordering with. Figure 1 features 6 spots where Malaysia is bordering with Thailand. The 6 spots are Bukit Kayu Hitam-Sadao, Padang Besar-Songkhla and Wang Kelian-Wang Prachan (Satun) in Perlis, Pengkalan Hulu-Betong in Perak, while Pengkalan Kubur-Tak Bai and Rantau Panjang-Sungai Golok are situated in Kelantan.

Figure 1: Malaysia Border areas with Thailand in Perlis, Perak and Kelantan

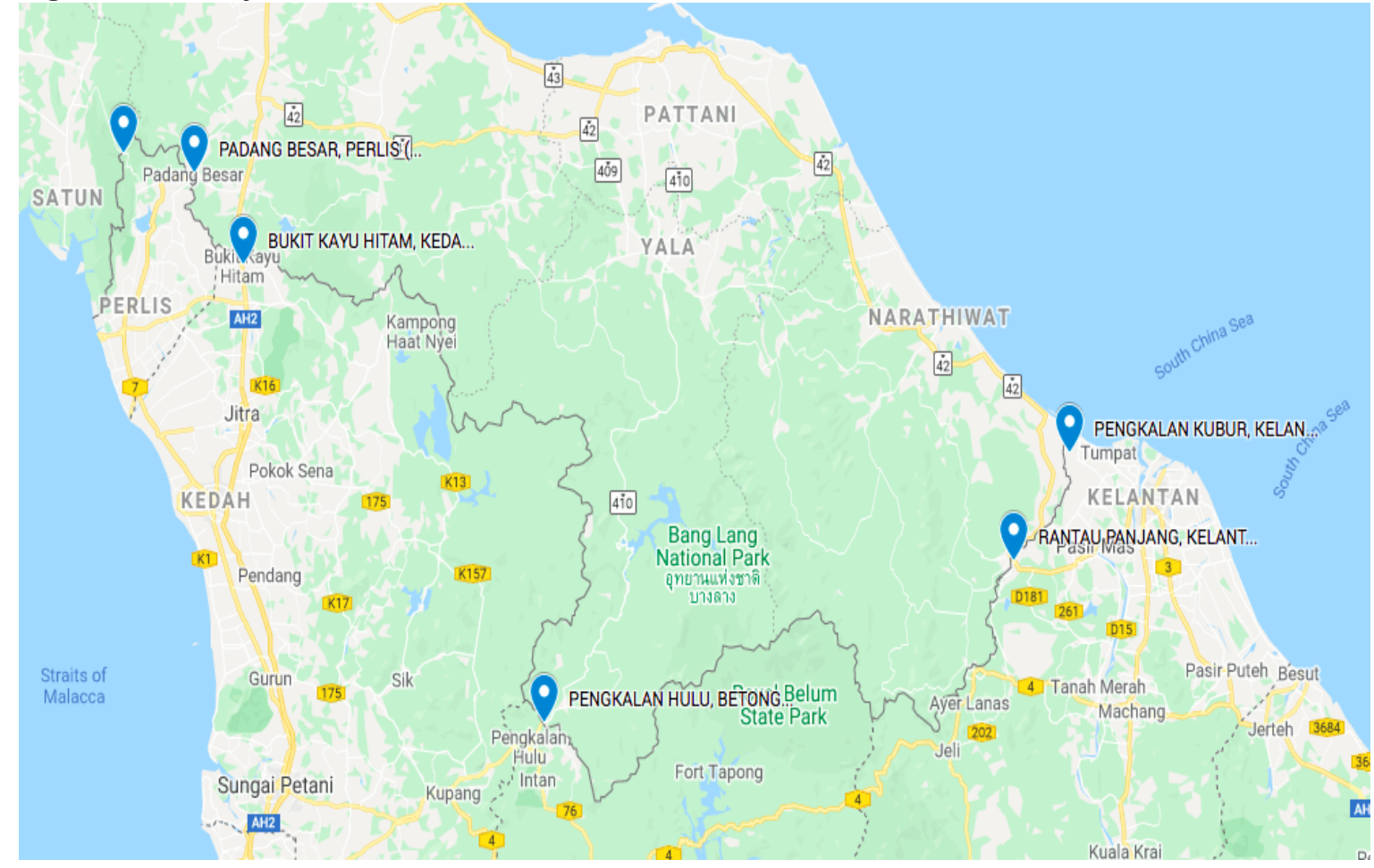




\section{SCIENCES}

Vol. 10 , No. 4, 2020, E-ISSN: 2226-3624 ㄷ 2020 HRMARS

Figure 2 depicts border areas in Johor/Singapore. They are specifically in Johor BahruWoodlands and Tanjung Kupang-Tuas. Figure 3 shows border areas in Sarawak/Indonesia. The common border area for Sarawak/Indonedia is in Tebedu, Serian, Sarawak-Entikong, West Kalimantan, Indonesia. Figure 4 indicates border area spots for Malaysia/Brunei in Sarawak. This involves for areas which are namely Limbang-Tutong, Lawas-Temburong, LimbangTemburong and Miri- Kuala Belait. Figure 4 also shows the possible area for border opening in Serudong, Kalabakan. Figure 5 shows the overall border areas in Malaysia.

Figure 2: Malaysia Border areas with Singapore in Johor

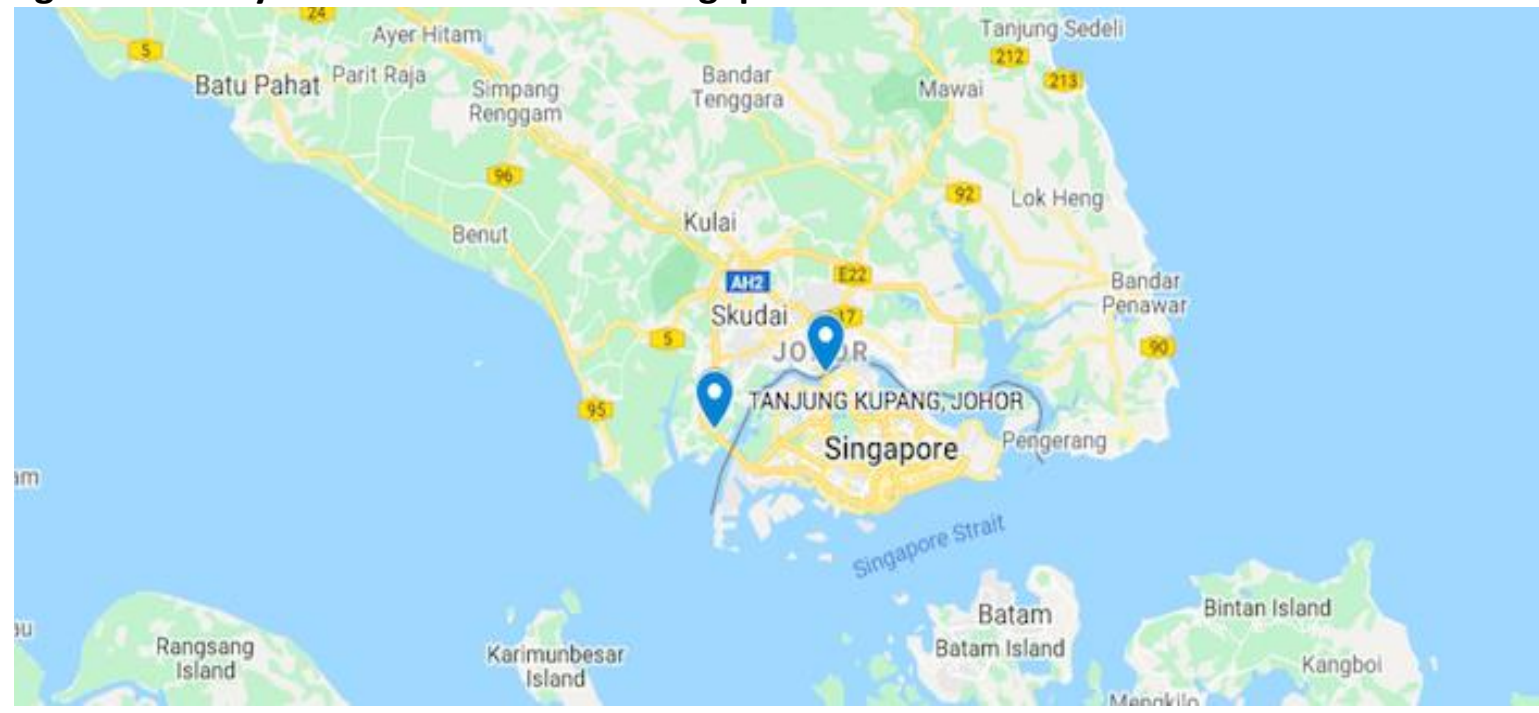

Figure 3: Malaysia Border area with Indonesia in Sarawak

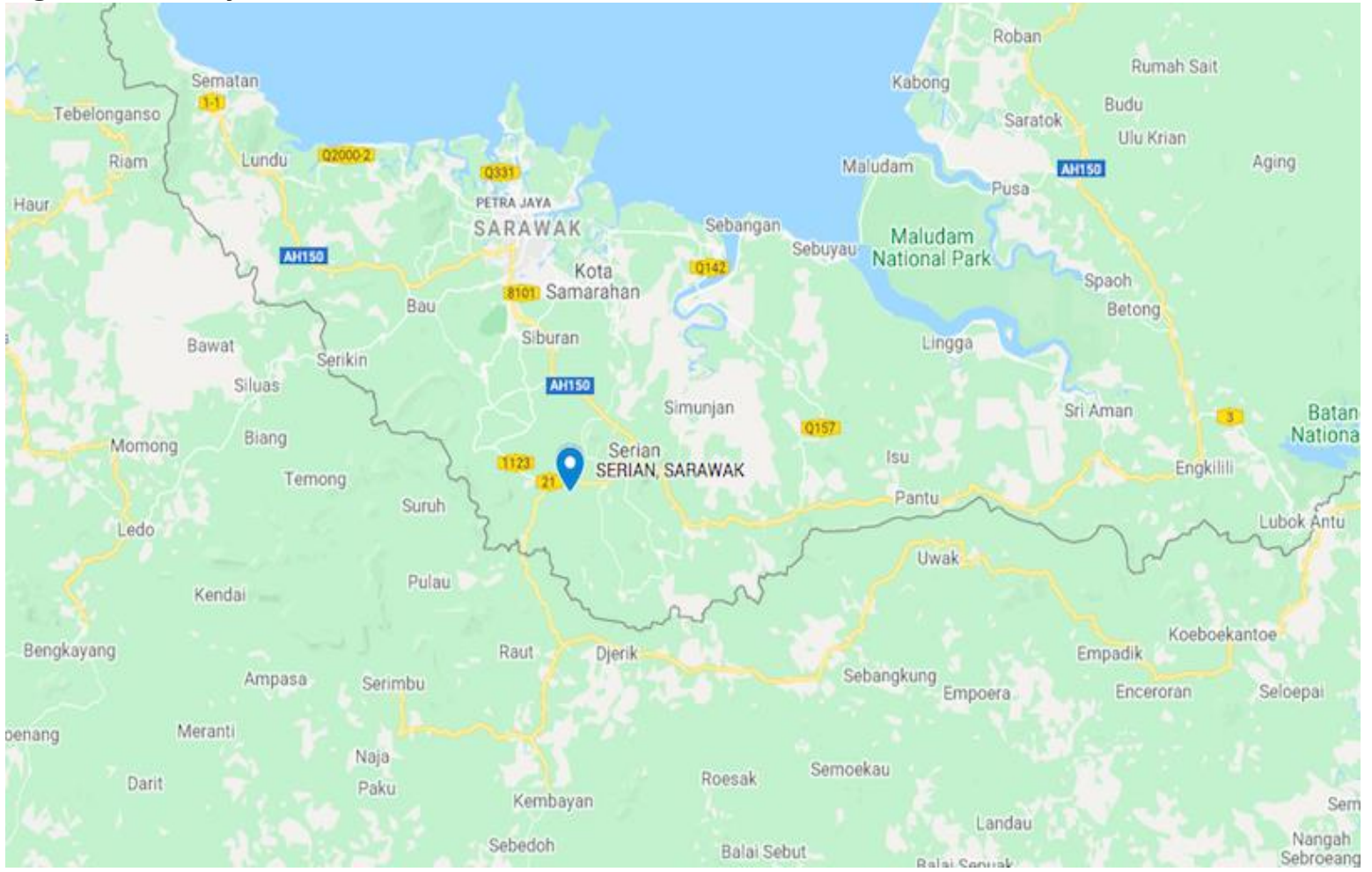


INTERNATIONAL JOURNAL OF ACADEMIC RESEARCH ECONOMICS AND MANAGEMENT SCIENCES

Vol. 10, No. 4, 2020, E-ISSN: 2226-3624 (C) 2020 HRMARS

Figure 4: Malaysia Border areas with Brunei in Sarawak

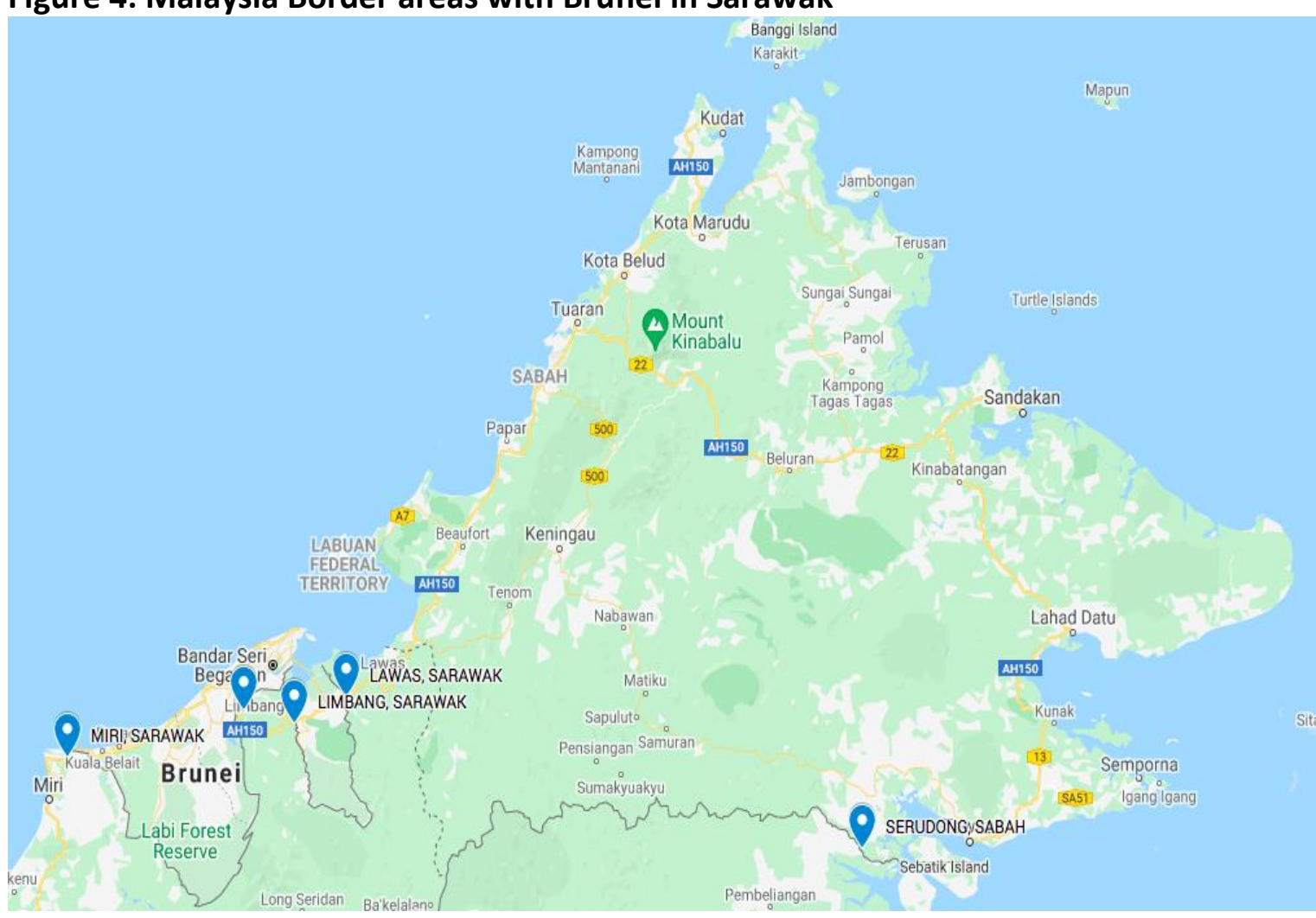

Figure 5: 14 Malaysia Border areas with neighboring countries

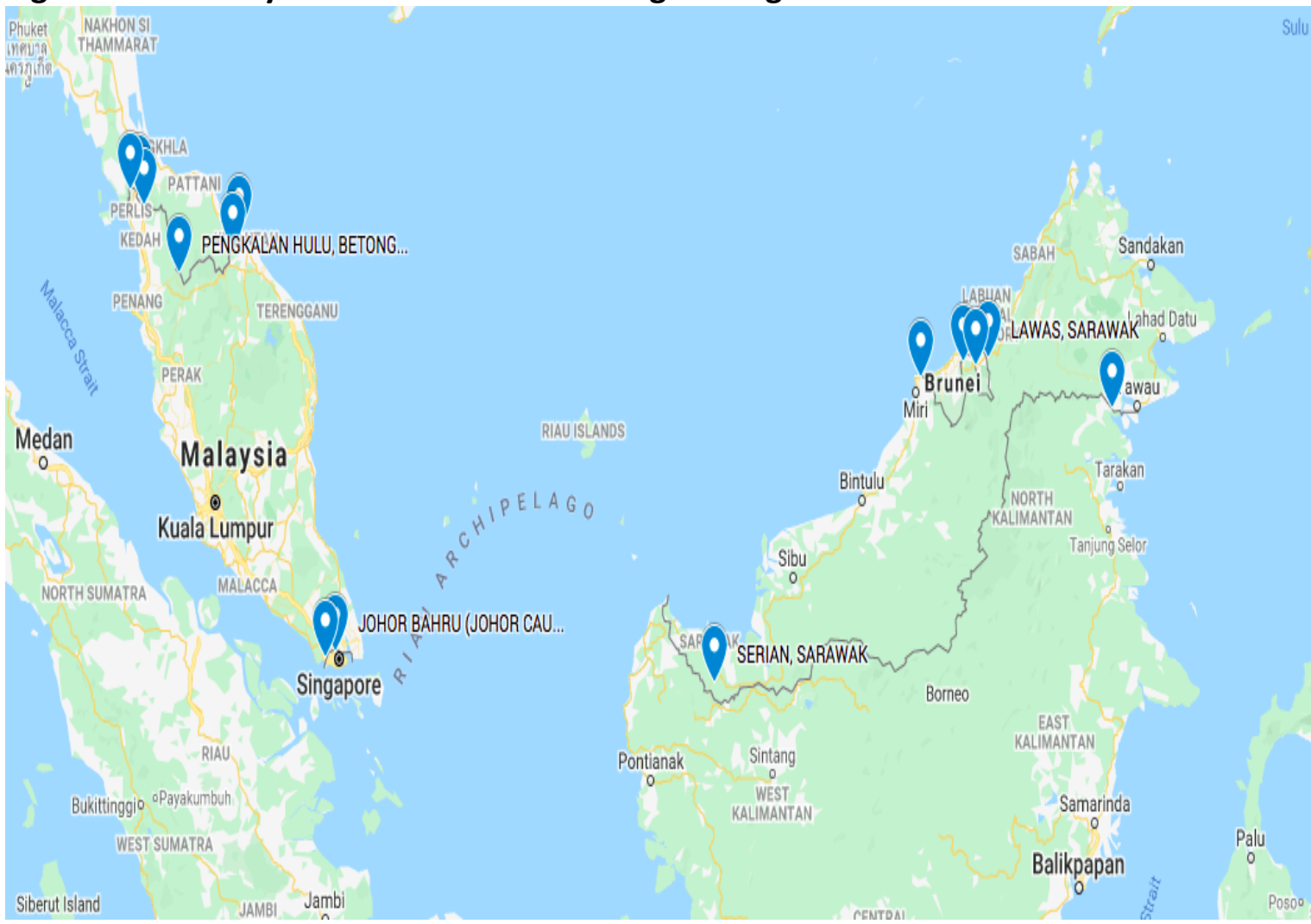


SCIENCES

Vol. 10 , No. 4, 2020, E-ISSN: 2226-3624 ㄷ 2020 HRMARS

\section{Literature Review}

There are many studies across different countries that have been conducted with regard to border towns. This can be seen for example in the work of Patty Kelly (2008) on which he studied the small Arizona town of Esperanza. Violence incidents among others are the things discussed in the study. The study describes the ways in which violence was found in Esperanz. The study also suggested that violence can be overcome through sustaining positive, community understanding, cultural connections, valuing positives, and empowering the community.

In the case of Malaysia, there were also some studies found. For example, the work of Ho Ching Goh (2014) discussed the state of tourism development in Perlis, where Malaysia borders Thailand. One of the many things mentioned in the study was that despite the state's tourism potentials, poor accessibility, improper and inappropriate development planning not in accordance to the uniqueness of local tourism resources, and poor maintenance had thwarted the potential role of tourism as a tool of development in the state. Hence, limiting its tourism function to that of a mere transit town and a minor border tourism destination. There are many other studies on border town, border areas or border related research to be mentioned. For instance, it can be found in the work of ( Pelican and Steinberger, 2017; Lord \& Tangtrongita, 2014; Idris et al., 2017; Najimudin et. al., 2020). On a whole, there are abundance of studies found that focus on border.

\section{Methodology}

50 key informants were engaged between the year 2019-2021 via focus group discussion or interview. The findings reported in the next section are based on the inputs obtained from various stakeholders and view of authors. The views presented are only the views of some key informants and may not represent the view of majority important stakeholders. The study may send signals for areas to be considered and further discussed by relevant stakeholders.

\section{Results \& Recommendations}

In general, majority of the stakeholders agreed with the idea of having border town in Kalabakan but with different opinions on various aspects such as location, size of town and development priority among others. 


\section{SCIENCES}

Vol. 10, No. 4, 2020, E-ISSN: 2226-3624 @ 2020 HRMARS

Table 1 highlights some of the key inputs from various stakeholders.

\begin{tabular}{|c|c|}
\hline ISSUES & EXPLANATIONS \\
\hline $\begin{array}{l}\text { Does Sabah really need a } \\
\text { new border town? Build a } \\
\text { new border township } \\
\text { (supply driven) VS let the } \\
\text { existing town naturally } \\
\text { expand. }\end{array}$ & $\begin{array}{l}\text { The basic fundamental question is whether or not Sabah needs } \\
\text { a new border town. Almost all stakeholders which being } \\
\text { consulted agreed with the idea of having a border town. The } \\
\text { argument was that, it was unfavourable if vehicles from or } \\
\text { moving to neighbouring country just passed by. They argued } \\
\text { that it is good if Kalabakan could benefit from the movement } \\
\text { of people activities in the border area by having border town. } \\
\text { Some pointed out that it is good if the new border town } \\
\text { establishment to come up together with dry port, special } \\
\text { economic zone and road link with Kalimantan or being } \\
\text { developed separately in different phases. } \\
\text { On the other hand, few felt that allowing the existing small } \\
\text { town to naturally expand as the cheapest and best option. They } \\
\text { argued that the state should only build a new township if there } \\
\text { was a real need. After all, few explained that Tawau was not } \\
\text { too far from Kalabakan. Building a new township would have } \\
\text { big financial implication and could affect environment if it } \\
\text { involved the use of forest land. }\end{array}$ \\
\hline $\begin{array}{l}\text { If the state decides to } \\
\text { have new border town, } \\
\text { what the size should be } \\
\text { like? }\end{array}$ & $\begin{array}{l}\text { If the state government and other stakeholders agree with the } \\
\text { new township idea, what is the best size like? What is the plan } \\
\text { for land use? Start with a small one, with few/some blocks of } \\
\text { commercial units at a designated area? or build a new township } \\
\text { with a quite complete infrastructure and government } \\
\text { departments and functions in place? For example, to have a } \\
\text { police station, proper hospital and other government services. }\end{array}$ \\
\hline Location of border town & $\begin{array}{l}\text { Some key stakeholders highlighted their concern with regard } \\
\text { to the exact location of border town. Would it be in the } \\
\text { existing small town, hence having expansion? Would it be in a } \\
\text { new area in such as Serudong or somewhere else? }\end{array}$ \\
\hline $\begin{array}{l}\text { Population in Kalabakan } \\
\text { is not that big and people } \\
\text { are scattered. }\end{array}$ & $\begin{array}{l}\text { Some stakeholders raised the issue of scattered population. } \\
\text { They were not highly concentrated in Pekan Kalabakan. Was it } \\
\text { economically wise to have a new border town when population } \\
\text { was scattered? }\end{array}$ \\
\hline $\begin{array}{l}\text { Should the government } \\
\text { intervene } \\
\text { invite/encourage } \\
\text { investors to build private } \\
\text { specialist hospital and } \\
\text { university in Kalabakan? }\end{array}$ & $\begin{array}{l}\text { Should the government intervene or invite/encourage } \\
\text { investors to build private specialist hospital and or university in } \\
\text { Kalabakan? Who shall bear the cost? }\end{array}$ \\
\hline
\end{tabular}


What are the things needed to add value to the new township?
To ensure that Kalabakan could tap the benefits from the opening up of border in Serudong-Simanggaris, some stakeholders believed that it was good to at least have some basic elements in border area such as clinic/hospital, hotel, bus terminal, new shop/commercial lots, banks, good transportation system, a tourism attraction spot such as museum, gallery, parks, shopping outlets/centre, international school, Polytechnic and or university among others. Other strategic proposal like special economic zone require further investigation. Feasibility study is important. Perhaps Sabah can learn from the experience of other countries.

Who shall undertake the project?
Many views were presented on the best way to build the new township/dry port/economic zone. One possible way besides appointing or involve local big player to do is by allowing foreign big player to carry out the project under BOT contract. Big player is a big company who can build and operate the project well and sustainably by connecting all the dots in a long business chain that can be linked with international market. After the contract expire, then only it is to be transferred or handed over to the government. Build, Operate and Transfer (BOT) contract involving main foreign player is seen by some as strategic move to have sustainable beneficial big project and avoiding white elephant project.

In sum, table 1 summarizes the issues or concerns of stakeholders and their views. The views are solely their idea which are based on their projection and experience, without proper study. Some of the suggestions involve huge budgetary implications and land use.

Figure 6 summarizes some recommendations proposed by stakeholders and researchers in this study which imply the elements that border area may have if the idea of border town put forth.

Figure 6 indicates that, it is recommended that the border town are furnished or equipped with healthcare services, education services, stable supply of water and electricity, digital as well as other basic infrastructures, security, safety and government other strategic functions, facilities for people's wellbeing and manufacturing plant, dry port, special border economic zone.

In addition to whatever is depicted in Figure 6, it is recommended that a more comprehensive study to be conducted to examine the effects of border town to Kalabakan and Sabah's economy by conducting a cost-benefit analysis. By conducting a comprehensive study and allowing further investigation, only then several questions depicted in Table 1 can be answered. The future study must come up with several assumptions with regard to the new border township such as size, land use size, location of new township, what basic town functions to be there and areas involved for the road link among others. Whatever being 


\section{SCIENCES}

Vol. 10, No. 4, 2020, E-ISSN: 2226-3624 @ 2020 HRMARS

recommended here is subject to further investigations such as impact on environment among others.

Furthermore, other strategic proposal such as the establishment of special economic zone need further study. Further discussion on which special economic zone model should be followed or even replicated require further study. There is no guarantee that whatever deem to be successful in another country will also be successful in Sabah.

Figure 6: Recommendations on things to consider to have in border town or areas

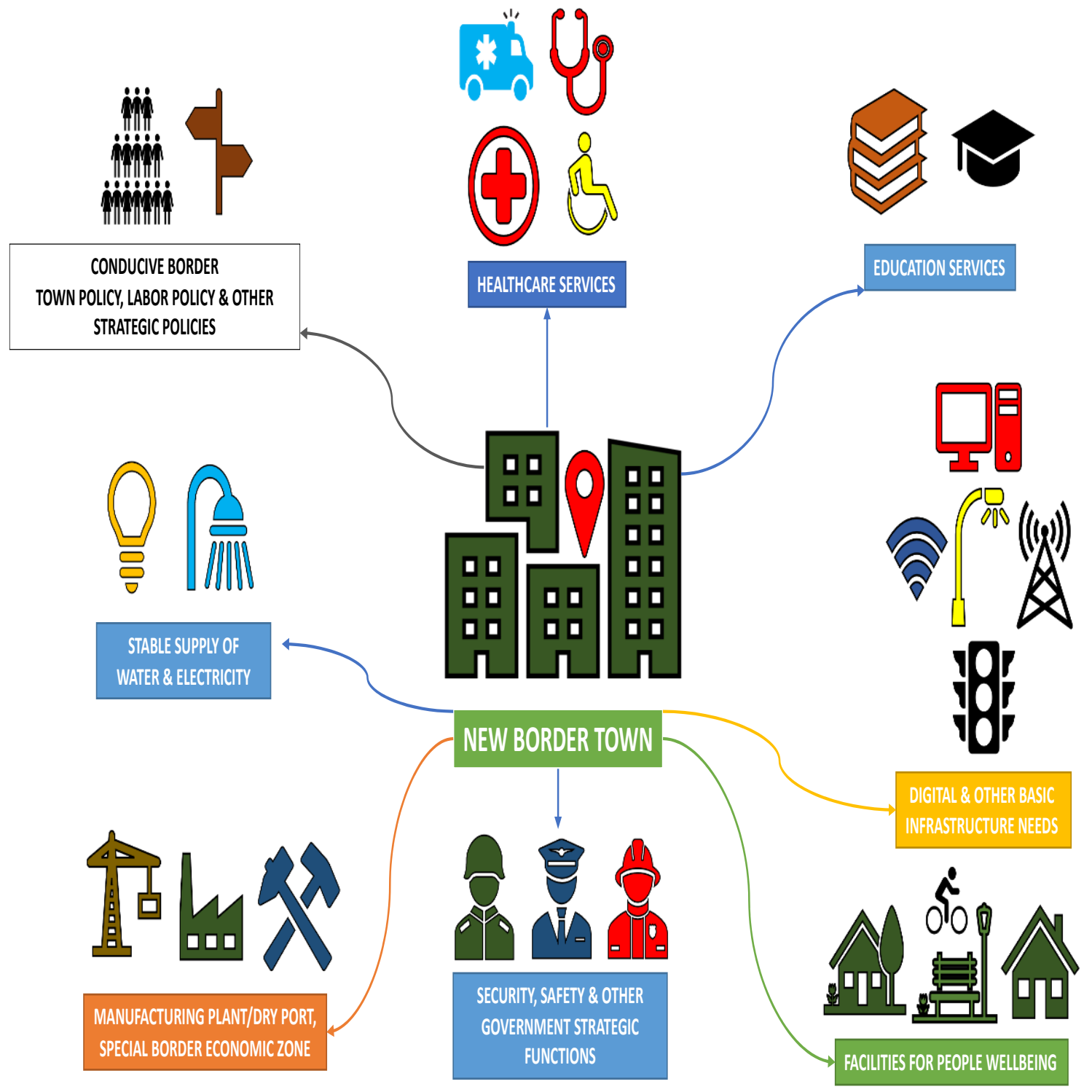

\section{Concluding Remarks}

Many suggestions have been raised with regard to the functions, impacts, potentials of a border town. With regard to the proposed border town in Serudong, several striking issues and reasonable points have been raised by stakeholders in Tawau and Kalabakan that worth further discussion and consideration. It is hoped that further interaction and engagement are made to harmonize the planning and implementation of projects in the border area. The idea 


\section{INTERNATIONAL JOURNAL OF ACADEMIC RESEARCH ECONOMICS AND MANAGEMENT}

SCIENCES

Vol. 10, No. 4, 2020, E-ISSN: 2226-3624 @ 2020 HRMARS

of special economic zone also need to be further specified and refined so that the idea will be a beneficial one for the economy. One of the many suggestions with regard to project execution of dry port/economic zone/border town is by involving it with big companies to build and operate under BOT contract. Big company which can connect all the dots in a long business chain can create a traffic to make the project working, sustainable and connected to international market.

\section{Acknowledgement}

The study is part of a research on Sabah-Kalimantan economy funded by Universiti Malaysia Sabah's grant (SDK0120-2019)

\section{References}

Goh, H. C. (2014). Border town issues in tourism development: The case of Perlis, Malaysia Kelly, P. (2008). Violence and Hope in a U.S.Mexico Border Town (review). January 2008, Anthropological Quarterly 81(3)

Lord, M., \& Tangtrongita, P. (2014). Special Border Economic Zone (SBEZ) in the IndonesiaMalaysia-Thailand Growth Triangle (IMT-GT). May.

Pelican, M., \& Steinberger, S. (2017). Melilla - Perspectives on a Border Town. Kölner Arbeitspapiere zur Ethnologie 6. Institut für Ethnologie, Universität zu Köln

Idris, R., Mansur, K., Idris, R. Z., Jamrin, Z. (2017). The Potential Benefit of Road Connectivity with Kalimantan from International Trade Perspective: The Effect of Cultural Affinity. Malaysian Journal of Business and Economics. 